sent the son and nephew of Godwine to Normandy as sureties of the grant. Dr. Giles affirms that this statement "is from W. Pictaviensis, who puts it in the mouth of the conqueror, but it is evidently false ; for Godwine died A.D. 1053, Siward A.D. 1055, and in 10.54 we find Eadward the Confessor sending for his nephew from Hungary, to make him his successor in the kingdom, who accordingly arrives in A.D. 1057, and dies almost immediately after. He could not, therefore have made the settlement as here asserted." Harold in the tapestry is represented as making oath to duke William, by which oath it is said the duke claimed his right to the English throne. In another part of the tapestry occur the words- " Hic dedit arma Willelm Haraldo," "Here William gave arms to Harold." Ordericus Vitalis informs us that Duke William presented Harold with arms and horses, "in contradiction to Wace, who in the Roman de Ron, laid the scene of the presentation of arms at Avranches, when William was on his march to Brittany."

\title{
An Account of the Bayeux Tapestry.
}

The celebrated tapestry of Bayeux which illustrates so much of the famous history of the Norman Conquest, consists of a web of linen nearly 19 inches in breadth and 214 feet in length; the memorable expedition from the embassy of Harold to the Norman court in 1065 , is successfully depicted. There are exhibited also several hundred figures of men, horses, beasts, birds, trees, castles, houses, and churches, with inscriptions over them explanatory of their meaning and history. The stitches, if they may be so called, are threads laid side by side and bound down at intervals by cross stitches or fastenings upon the said linen or cloth ; the parts intended to represent flesh are untouched by the needle. The colours are generally faded on bluish green, crimson, and pink. The finest copy that has ever been taken of the Bayeux Tapestry will be found in the South Kensington Museum. There is a good copy in the "Vetusta Monumenta," drawn many years ago by Stothard. The translators of "Master Wace his Chronicle," 
have given a number of illustrations from this tapestry similar to those given by Mr. Stothard in 1819. With regard to these illustrations it is conjectured that Wace must have seen the Bayeux tapestry before or at the time of writing his poem. This supposition is supported by the fact of his having held an ecclesiastical dignity in the chapel of the Bayeux Cathedral. This "Worsted Chronicle" is set down by some persons as the work of Matilda of Flanders, queen of William the Conqueror, but upon investigation it is found to be neither the work of the first nor the second Matilda; it was executed by order of Odo, Bishop of Bayeux, "uterine" brother of the Conqueror, "who alone had the power to deposit and display the representation of a subject from profane history in a sacred edifice." Hume has attributed the work to the third Empress Matilda, daughter of Henry I. Odo is said by Thorpe to be the son of Arlette by her husband Herluin de Conteville. He was contemporary with Harold and William, and is mentioned as bishop in 1066.* This bishop appears in effigy on the tapestry on horseback clad in armour, holding a club with which as the inscription states, "he encouraged the youths."

Harold at his coronation is seen seated on his throne, listening apparently with great attention to two messengers who no doubt had some important matter to communicate to him. Some have suggested that these messengers brought the news of the landing of his brother Tostig and the Norwegians. Others more justly conjecture that the two men represent Duke William's ambassadors who were sent to expostulate with Harold on his claiming the crown of England. The words above the throne are- " Here sits Harold, King of the English.-Stigand, Archbishop." Harold holds a sceptre, and in his left a globe surmounted by a cross. On his left is Stigand, who is said to have crowned him in defiance of the Pope's interdiction, and for which act he afterwards suffered at the hands of William. The early writers, at least several of them, affirm that Harold was crowned by Aldred, Archbishop of York. 